\title{
MUDANÇAS AMBIENTAIS QUATERNÁRIAS NO MEGALEQUE FLUVIAL DO AQUIDAUANA, BORDA SUDESTE DO PANTANAL MATOGROSSENSE
}

\author{
QUATERNARY ENVIRONMENTAL CHANGES IN THE MEGAFAN \\ AQUIDAUANA, EDGE SOUTHEAST OF PANTANAL \\ CAMBIOS AMBIENTALES CUATERNARIAS EM EL RIO \\ AQUIDAUANA, BORDA SUDESTE DEL PANTANAL
}

\section{Eliézer Cece Gregório}

Mestre em Geografia pela Universidade Federal de Mato Grosso do Sul. Instituto Federal de Mato Grosso do Sul. Campus de Aquidauana. R. José Tadao Arima, 222 - Vila Ycaraí. Aquidauana - MS, 79200-000; e-mail: eliezergrego@yahoo.com.br

\section{Edna Maria Facincani}

Pós- Doutorado em Geociências (Geociências e Meio Ambiente) pela Universidade Estadual Paulista. Professora Dra. da FAENG/UFMS (Faculdade das Engenharias, Arquitetura e Urbanismo e Geografia da Universidade Federal de Mato Grosso do Sul), Campus de Campo Grande/MS - Brasil - bloco 7 A. E-mail:edna_facincani@hotmail.com

\section{Gustavo Marques e Amorim}

Doutor em Geociências - Geologia Regional - UNESP. Pesquisador de Desenvolvimento Científico Regional - DCR, CNPQ - FUNDECT - UFMS - Universidade Federal de Mato Grosso do Sul, Reitoria. Fundação Universidade Federal de Mato Grosso do Sul - INFI (Instituto de Física da Universidade Federal de Mato Grosso do Sul) - bloco 7A. Universitário. Campo Grande, MS - Brasil; E-mail: gustavo_m_amorim@hotmail.com

\section{RESUMO}

O Megaleque do Aquidauana é um trato de sistemas deposicionais, em que o rio Paraguai é a drenagem principal, coletora das águas de diversos leques fluviais, constituindo de uma importante feição geomorfológica instalada na Borda Sudeste do Pantanal Mato-Grossense, com área de aproximadamente $3.783 .48 \mathrm{~km}^{2}$. No presente trabalho, utilizando dados orbitais e técnicas de interpretação visual de imagens a área foi compartimentada em três lobos deposicionais distintos denominados de antigo, préatual e atual. Estas unidades apresentam em sua superfície geoformas atuais e relictas que evidenciam mudanças ambientais que vem ocorrendo na área desde o Pleistoceno até o presente. As mudanças são principalmente de cunho paleohidrológico, dentre as quais podem ser destacadas os lobos deposicionais (relicto e atual) e a planície incisa (abandonado e ativo), feições geomorfológicas que demonstram a paisagem do Megaleque Fluvial do Aquidauana se alterando durante o Quaternário.

Palavras-chave: Megaleque Fluvial do Aquidauana, Mudanças Ambientais, Geotecnologias. 


\section{ABSTRACT}

The Aquidauana megafan is a depositional system tract in which the Paraguay River is the main drainage, collecting water from various rivers fans, constituting an important geomorphological feature installed on the Edge southeastern Mato Grosso Pantanal, with an area of approximately $3,783.48 \mathrm{~km}^{2}$. In this study, using orbital data and techniques of visual image interpretation the area was compartmentalized into three distinct depositional lobes called ancient, pre-current and current. These units present on the surface current and relicts landforms that show environmental changes that have occurred in the area since the Pleistocene to the present. The changes are mainly paleohidrological nature, among which can be highlighted the depositional lobes (relict and current) and incised plain (abandoned and active), morphological features that show the landscape of the Aquidauana River megafan been changing during the Quaternary.

Keywords: megafan Fluvial of Aquidauana, Environmental Change, Geotechnology.

\section{RESUMÉN}

El megafan de Aquidauana es un sistema de vías de sedimentación en el río Paraguay es el principal drenaje, recolección de agua de varios ventiladores de ríos, lo que constituye una importante característica geomorfológica instalado en el borde sureste Pantanal de Mato Grosso, con una superficie aproximada de 3.783 .48 kilómetro. En este estudio, el uso de datos y técnicas de la zona de interpretación de imágenes visuales orbitales fue compartimentada en tres lóbulos deposicionales distintas llamadas antiguo, pre largo y corto plazo. Estas unidades presentes en las corrientes superficiales y relictas accidentes geográficos que muestran los cambios ambientales que han ocurrido en la zona desde el Pleistoceno hasta la actualidad. Los cambios son principalmente la naturaleza paleohidrológico, entre los que pueden destacarse los lóbulos de deposición (relictos y actuales) y una incisión simple (abandonada y activa), los rasgos morfológicos que muestran el paisaje del río Aquidauana megafan ido cambiando durante el Cuaternario.

Palabras clave: megafan Fluvial de Aquidauana, cambio ambiental, Geotecnologias. 


\section{INTRODUÇÃO}

A história natural do planeta no decorrer do tempo geológico foi marcada por inúmeras e profundas mudanças ambientais impressas por toda a superfície da Terra, sobretudo as que ocorreram no Quaternário, o que tem despertado nas comunidades científicas o interesse em compreender o ciclo geológico deste período, em função das flutuações climáticas e das variações do nível do mar. Paralelamente, o estudo do Quaternário continental também passa a ganhar relevância (Assine, 2003, Facincani, 2007 e Kuerten, 2010).

O Quaternário é um período curto e recente, entretanto, tem sido palco de profundas mudanças ambientais, sendo que seus registros se encontram melhor preservadas do que em períodos anteriores, tornando os estudos do Quaternário continental um importante elo entre presente e passado, permitindo diagnosticar as mudanças ambientais pouco remotas e prognosticar as futuras alterações na paisagem (Zani, 2008).

Nesta perspectiva, a planície pantaneira é um espaço relevante a ser pesquisado para compreender as mudanças ambientais recentes, uma vez que as morfologias que abarcam o sistema deposicional da área são elementos que ajudam no conhecimento da sua gênese e na configuração atual da paisagem. Na Borda Sudeste do Pantanal Mato-Grossense, se destaca o Megaleque Fluvial do Aquidauana (Figura 1), que apresenta diversas feições atuais e reliquiares, testemunhando um anfiteatro de mudanças ambientais que vem ocorrendo na área desde o Pleistoceno até os dias atuais. 
Figura 1. Localização do Megaleque Fluvial do Aquidauana, na Borda Sudeste da Bacia Sedimentar do Pantanal e seu posicionamento no Estado de Mato Grosso do Sul.

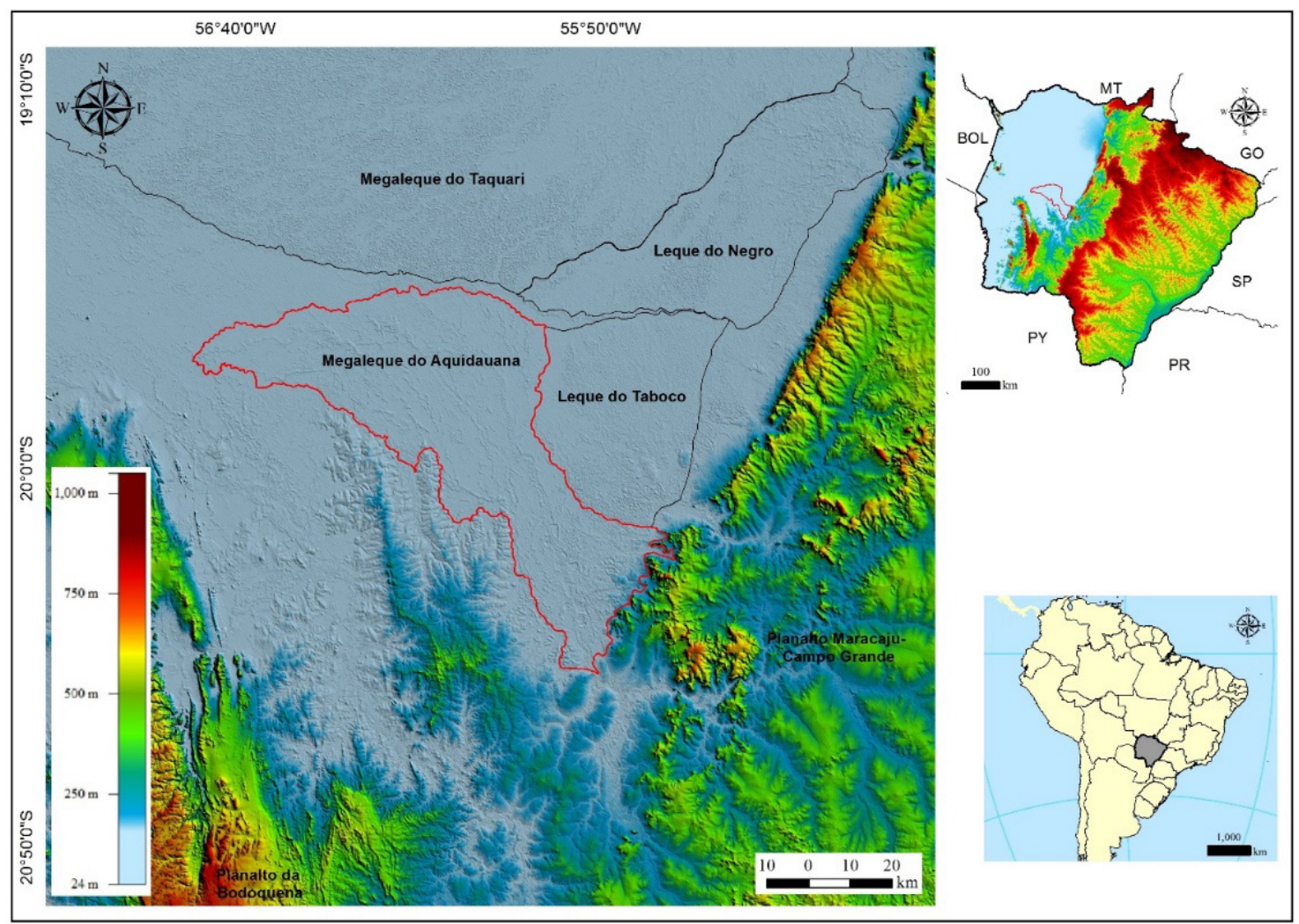

Fonte: Adaptado de (Valeriano, 2008) (Imagem SRTM, TOPODATA, 30 M. Ela. e Ed. Cunha. E. R., 2015).

Neste sentido o escopo deste trabalho é analisar as mudanças ambientais ocorridas no Megaleque Fluvial do Aquidauana, com ênfase nos processos e formas que atuaram na gênese e evolução deste trato de sistema deposicional de origem aluvial desde o Pleistoceno até o Holoceno.

As mudanças ambientais da área correspondem principalmente às de cunho paleohidrológico, que submetidos às condições ambientais pretéritas, foram alterando o curso do rio Aquidauana resultando na atualidade em uma complexa rede de paleocanais, meandros abandonados, lagoas em meandros e frequentes processos de avulsão. Estes fenômenos acarretaram no surgimento de outras feições geomorfológicas que quando combinadas são responsáveis pela atual evolução geomórfica deste ambiente de sedimentação.

\section{PROCEDIMENTOS METODOLÓGICOS}

A compartimentação geomorfológica e análise das mudanças ambientais da área de estudo demandou o uso de imagens orbitais do satélite: 
- Landsat 8 sensor OLI (Operational Land Imager), datada de 20/08/2014 órbita/ ponto 225/74 e 226/74 em formato TIFF/GEOTIFF, com resolução espacial de $30 \mathrm{~m}$ e banda 8, pancromática com resolução espacial de 15 m (Knight e Kvaran, 2014);

- Imagem Landsat 7, sensor ETM+, ZULU, 2000. Imagem de radar interferométrico SRTM (Shuttle Radar Topographic Mission), TOPODATA, em formato GEOTIFF, com resolução espacial de $30 \mathrm{~m}$ (Valeriano, 2008);

- Imagens ópticas de alta resolução do satélite GeoEye, datada de julho de 2013 (ArcGIS $10^{\circledast}$ online) e outras adquiridas no site do Google Earth ${ }^{\circledast}$ (Corporation, 2015);

- Fotografias aéreas na escala 1:60.000, USAF, 1965, 1966, 1969 e arquivos vetoriais do CPRM-Geologia e recursos naturais do Estado de Mato Grosso do Sul. Escala 1:1.000.000, 2006.

Após a compilação das imagens orbitais a ser utilizadas, estas foram inseridas em um Sistema de Informação Geográfica (SIG), $\operatorname{ArcGis}^{\circledast} 10$, no qual se interpretou e mapeou as unidades morfológicas que evidenciam mudanças ambientais na área de estudo. $\mathrm{Na}$ interpretação das imagens de satélites para aquisição das informações necessárias foi utilizada a proposta de Soares e Fiori (Soares e Fiori, 1976), simplificadamente agrupadas em três processos:

- Foto-leitura: Reconhecimento e identificação dos elementos das imagens com os objetos correspondentes e sua repartição;

- Foto-análise: estudo das relações entre as imagens, associação e ordenação das partes das imagens;

- Foto-interpretação: estudo do material iconográfico buscando à descoberta e avaliação por métodos indutivos, dedutivos e comparativos do significado, função e relação dos objetos correspondentes às imagens.

Nos lobos distributários atual e abandonado, a compartimentação seguiu-se a partir de critérios morfológicos, baseados na orientação e truncamento de paleocanais proposto por (Assine, 2003).

Os trabalhos de campo foram realizados em três etapas sendo feitos nos lobos antigos, pré-atual e atual, nos meses de agosto de 2014 e junho/julho de 2015. Foram feitos levantamentos tanto nos lobos do megaleque quanto ao longo do canal fluvial do rio Aquidauana, percorrido desde a área urbana de Aquidauana até a confluência com o rio Miranda (Figura 2). Quanto às feições geomorfológicas foram observadas em campo: re- 
de de drenagem, paleocanais distributários, diques marginais, terraços marginais, meandros, meandros abandonados, cinturão de meandros e barras em pontal, planície fluvial incisa, crevasse splays e avulsão, visando comprovar o mapeamento geomorfológico feito em laboratório.

Figura 2. Etapas de campo: levantamento de descrição geomorfológica no lobo antigo sede da Fazenda Pequi, margem esquerda do rio Aquidauana. Localização. Data: agosto de 2014 (A). Canal fluvial do rio Aquidauana no lobo atual sede da Fazenda Touro Morto (B). Localização: Data: julho de 2015 (B).

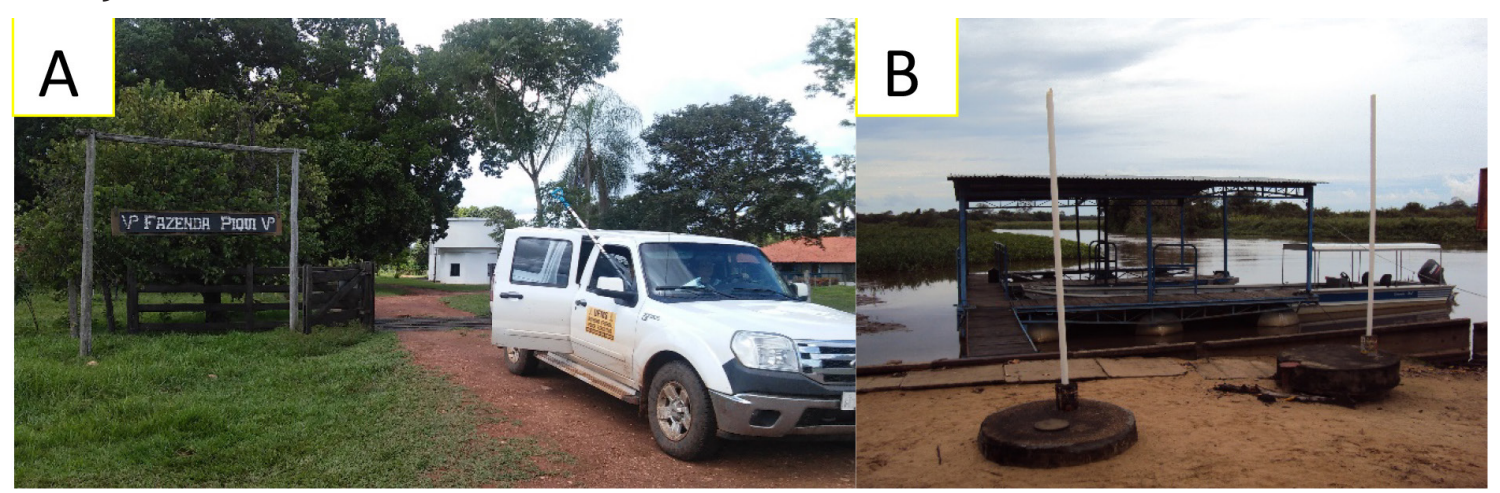

Fonte: Gregório, E.C. (2014)

\section{RESULTADOS}

Os sedimentos erodidos nos planaltos são transportados para a planície da Borda Sudeste do Pantanal Mato-Grossense (na depressão de Miranda-Aquidauana), onde o rio Aquidauana vem construindo um megaleque fluvial, com padrão de dispersão e de paleocanais para NNW.

O primeiro resultado obtido para a área de estudo (Megaleque Fluvial do Aquidauana) foi uma composição, que permitiu visualizar com clareza que esta possui sua bacia de captação instalada no Planalto de Maracaju-Campo Grande, que compõe a bacia hidrográfica do rio Aquidauana, com área de aproximadamente $15.675 \mathrm{~km}^{2}$, fluindo de direção leste para oeste em direção contrária ao mergulho das rochas sedimentares paleozoicas e mesozoicas da Bacia do Paraná (Figura 3). 
Figura 3. Bacia de captação do Megaleque Fluvial do Aquidauana.

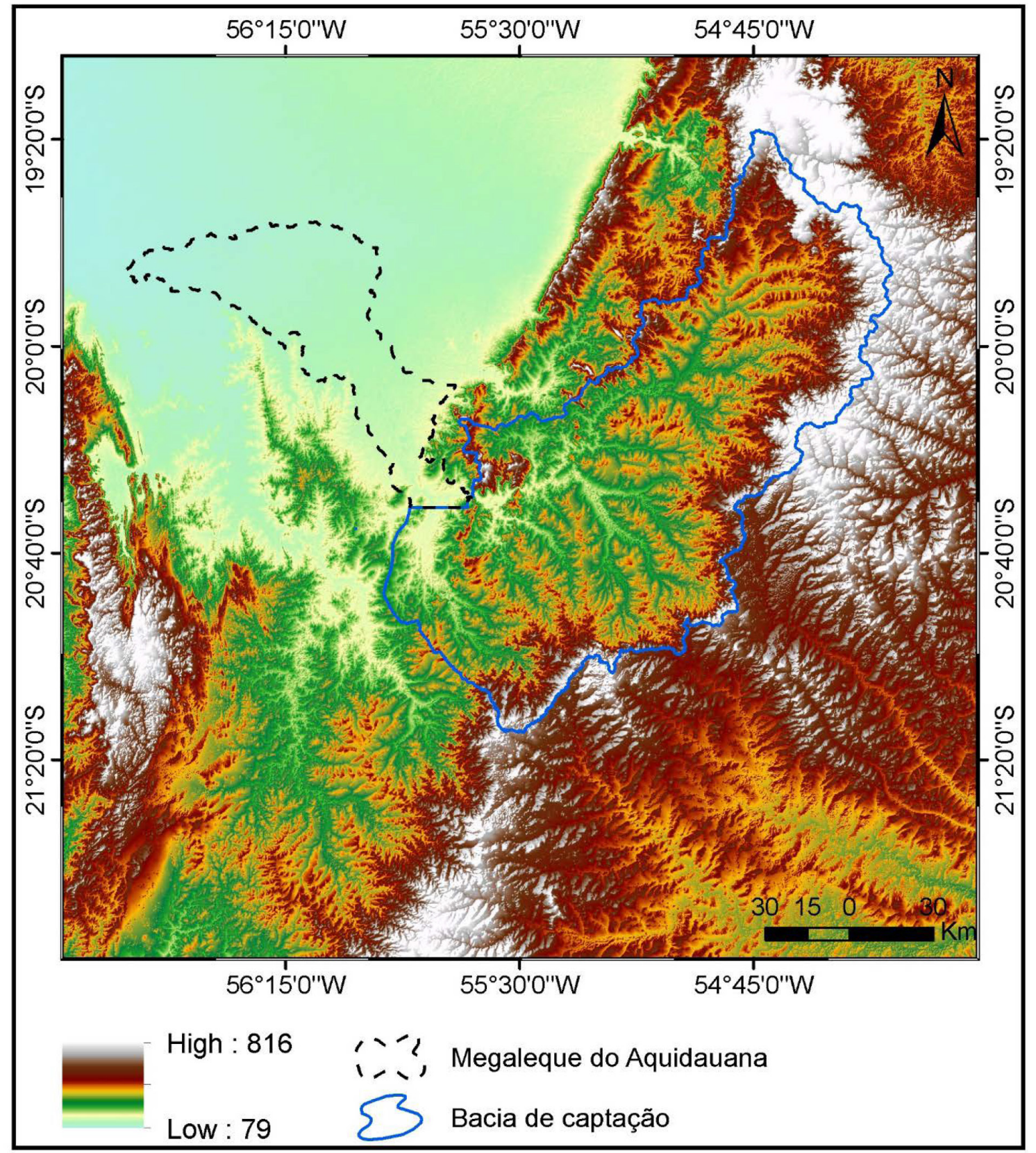

Fonte: Adpatado de (Valeriano, 2008). Imagem SRTM, TopoData 30m. Elaboração e Edição: GREGÓRIO, E. C., (2015).

A bacia de captação no planalto é composta por rios com sistema do tipo tributário. Na medida em que adentra pela planície pantaneira passa a ter um padrão distributário até a confluência com o rio Miranda. As cotas altimétricas variam entre $160 \mathrm{~m}$ no seu ápice à 90m na sua base, sendo que, o perfil longitudinal decresce da porção proximal para a distal, tornando a geometria do perfil longitudinal côncavo e transversal, ligeiramente convexo para cima, que é uma característica predominante em megaleques fluviais. 
O Megaleque Fluvial do Aquidauana está compartimentado em três lobos deposicionais distintos denominados por área: lobo antigo $\left(2771,1 \mathrm{~km}^{2}\right)$, pré-atual $\left(243,07 \mathrm{Km}^{2}\right)$, atual $\left(506,64 \mathrm{~km}^{2}\right)$ e uma planície meandrante de baixo entrincheiramento $\left(262,67 \mathrm{~km}^{2}\right)$, possuindo aproximadamente $3.783 .48 \mathrm{~km}^{2}$, conforme Figura 4 .

\section{Figura 4. Unidades geomorfológicas e quantitativo em $\mathrm{Km}^{2}$, presentes no Megaleque Fluvial} do Aquidauana.

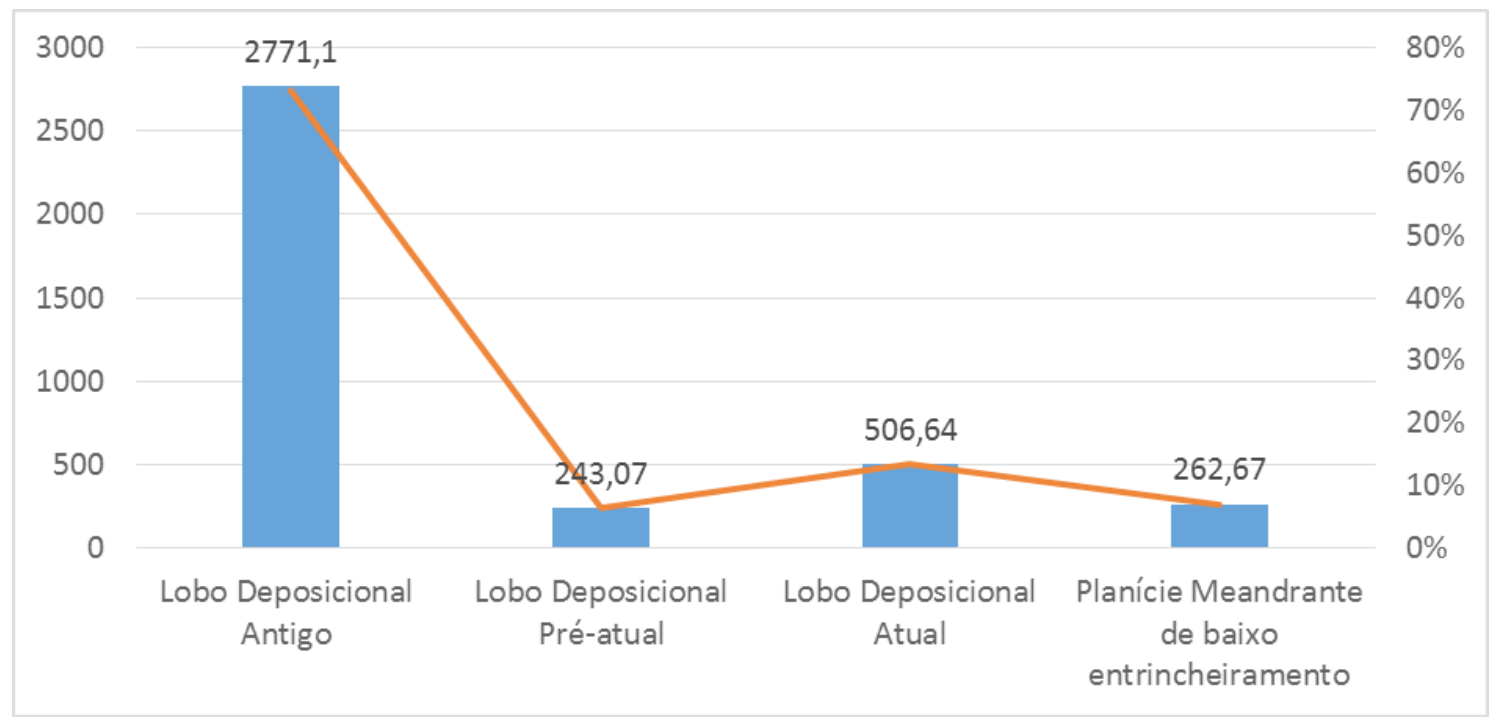

Esses compartimentos geomorfológicos possuem em sua superfície geoformas que permitem delinear uma sucessão de eventos geomorfológicos que são responsáveis pela evolução do Megaleque Fluvial do Aquidauana o que evidencia mudanças ambientais ocorridas na área, como segue.

\section{MUDANÇAS AMBIENTAIS NO MEGALEQUE FLUVIAL DO AQUIDAUANA}

A partir da cidade de Aquidauana o rio percorre aproximadamente $170 \mathrm{~km}$, confinado em um cinturão de meandros (meandering belt), com cerca de 2,5km de largura, de direção NW-SE.

O escoamento fluvial é confinado dentro do vale inciso, a velocidade do fluxo da água é maior neste compartimento, não há perdas de água durante as cheias por avulsão e há pouca variação nas medidas de vazão nas estações fluviométricas. Quando o rio Aquidauana deflete para WNW e entra no lobo distributário atual, o canal adquire padrão distributário, perdendo água para a planície de inundação não só devido ao extravasamento, mas também devido à existência de pontos de rompimento de diques e de construção de leques de espraiamento. 
As feições geomorfológicas presentes no Megaleque Fluvial do Aquidauana têm mudado desde o final do Pleistoceno numa adaptação ao clima do Holoceno mais quente e úmido (Figura 5). O sistema de drenagem foi reorganizado e canais temporários tornaram-se permanentes que estão registradas nos lobos e na planície incisa e retratam mudanças ambientais na paisagem, tais como: paleocanais, cinturão de meandros abandonados, planície incisa abandonada, paleodiques marginais, lobos antigo e pré-atual (abandonado) e atual, crevasse splays e diques marginais marcados por padrão de drenagem, essencialmente distributários.

Figura 5. Mudanças ambientais no Megaleque Fluvial do Aquidauana.

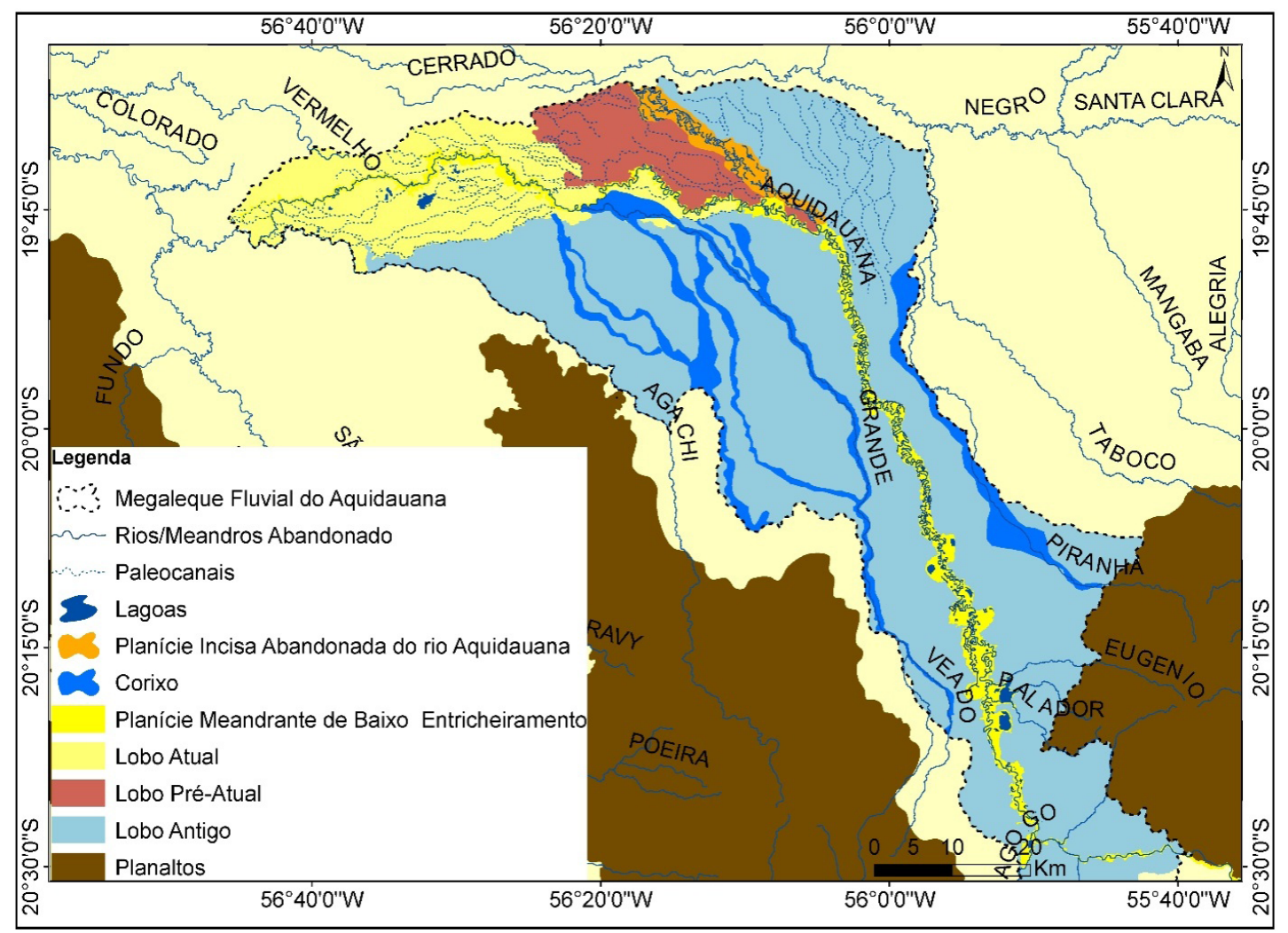

Fonte: GREGÓRIO, E. C., 2015.

As morfologias presentes na área que foram cartografadas são formas atualmente visíveis, no entanto, para que elas existam ocorreram eventos em condições ambientais pretéritas específicas e as marcas registradas na paisagem são as principais evidências de mudanças do ambiente na área de estudo, detalhadas a seguir. 


\section{PLANÍCIE INCISA HOLOCÊNICA}

O rio Aquidauana, quando adentra na planície pantaneira, se encontra encaixado em uma planície meandrante incisa de idade holocênica, que por sua vez está assentado em rochas sedimentar e metamórfica. A partir do sítio urbano de Aquidauana até a Fazenda Retirinho o rio percorre no cinturão de meandros que possui aproximadamente $170 \mathrm{~km}$ de extensão de direção NW-SE. Toda a água que vem do planalto através de rios tributários e afluentes do rio Aquidauana é confinada essencialmente, na planície incisa que alimenta o sistema distributário do lobo atual. Assim, nesse compartimento não há extravasamento de água, por estar confinado em terraços marginais em torno de 6 metros de altura.

A largura do cinturão de meandros abandonado decresce de montante para a jusante e na porção proximal do megaleque atinge sua maior expressão com cerca de $6 \mathrm{~km}$ de largura quando próximo ao fim do cinturão de meandros chega a 1,5 km de largura, demonstrando que o rio Aquidauana possui grande mobilidade lateral. Nesse compartimento o rio apresenta alta sinuosidade em torno de 1,5. As feições geomorfológicas encontradas são: barras em pontal, terraços e diques marginais, lagoas, lagoas em meandros e paleocanais (Figuras 6 A/B e 7 A/B).

Figura 6A/B. Cinturão de meandros abandonado na porção proximal do Megaleque Fluvial do Aquidauana. (A) Imagem LandSat 8 OLI, bandas 4B5G6B. (B) Mapeamento elaborado.

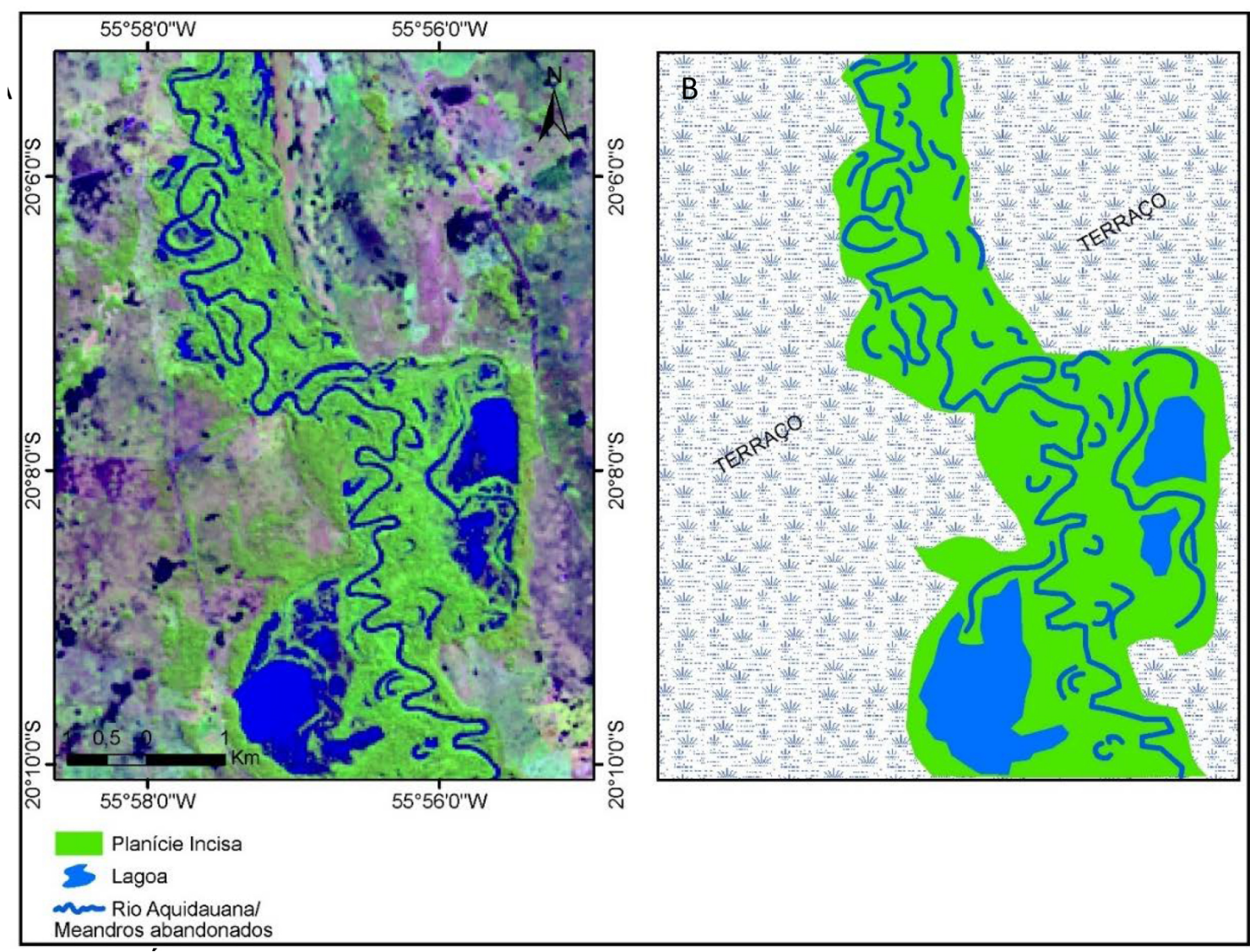


Figura 7. Terraço marginal e barras em pontal próximo a Fazenda Anhumas na porção superior do Megaleque Fluvial do Aquidauana (A). Localização (UTM-7757490/616861).

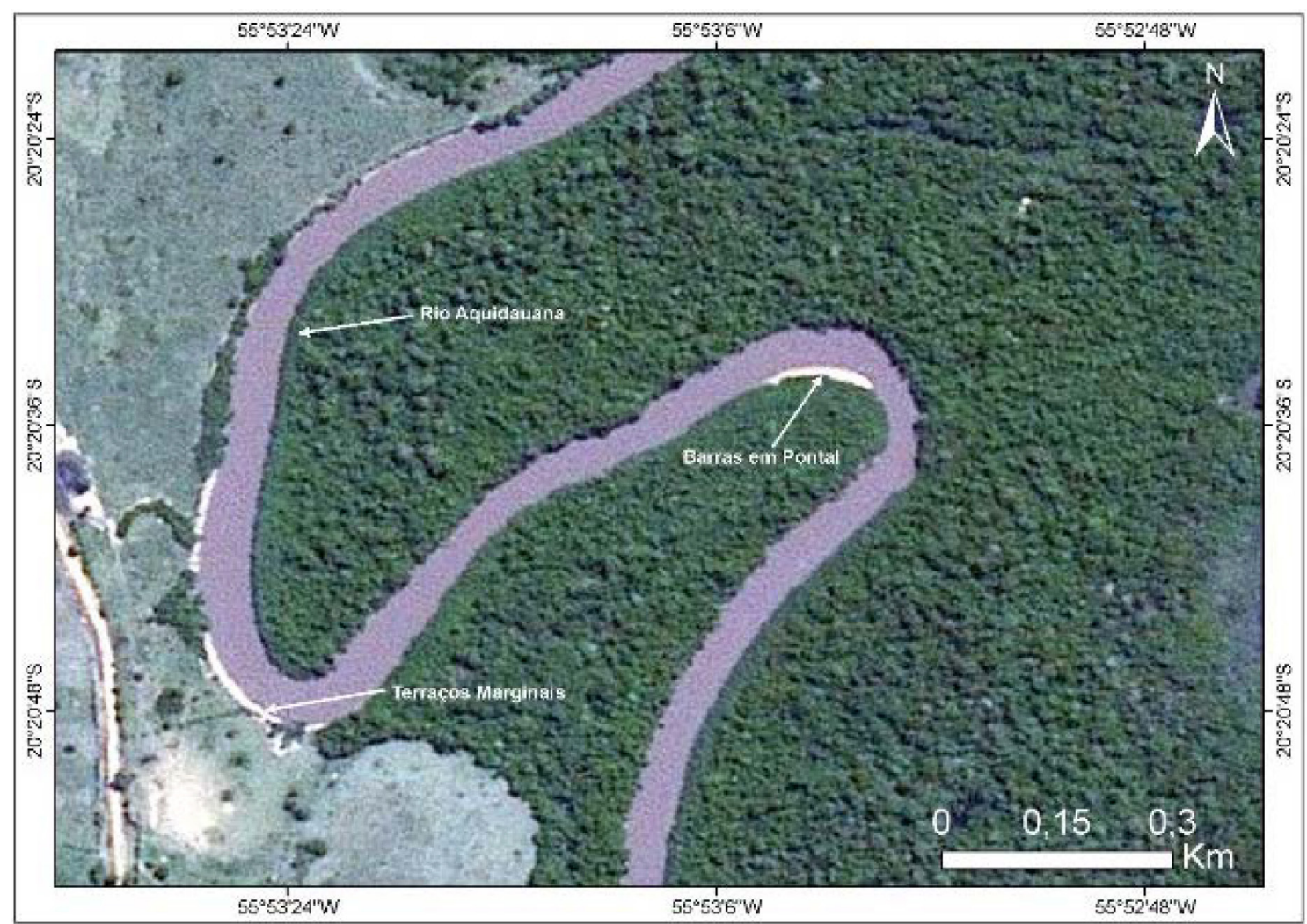

Fonte: GREGÓRIO, E. C. (2015). (Imagem BaseMap Arcgis ${ }^{\circledR}$ online).

Observa-se que no cinturão de meandros abandonado, há uma densa vegetação de estrato arbóreo, que permite delimitar com certa precisão a largura desta unidade e observar quando os terraços atingem a margem do rio, como mostrado na Figura 6. Em alguns casos por influência da cobertura vegetal, cria-se a falsa sensação de que a planície incisa se encontra em cotas altimétricas superiores aos do terraço, quando de fato são os terraços que estão em um patamar mais elevado que o vale entrincheirado.

$\mathrm{Na}$ faixa de meandros abandonados não existe cronologia padronizada para que ela ocorra, visto que resulta da carga de sedimentos oriundos dos planaltos e do grau de inundação em determinadas época do ano, o que pode provocar assoreamentos de diversos níveis no canal, facilitando o corte do meandro. Um exemplo contrastante ocorreu nas proximidades da área urbana do município de Aquidauana, no arrombado Volta Grande foi identificado que levou intervalo de tempo de 14 anos para que houvesse o rompimento do canal, provavelmente devido às magnitudes das enchentes serem maior nesse período, o que consequentemente, denota mais carga de sedimentos (Figura 8). 
Figura 8: Arrombado Volta Grande nas proximidades do sítio urbano do município de Aquidauana.

() $\times$

๑) (1)

อ o

$\approx 0$

$\pi z$

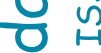

$\frac{0}{2}$
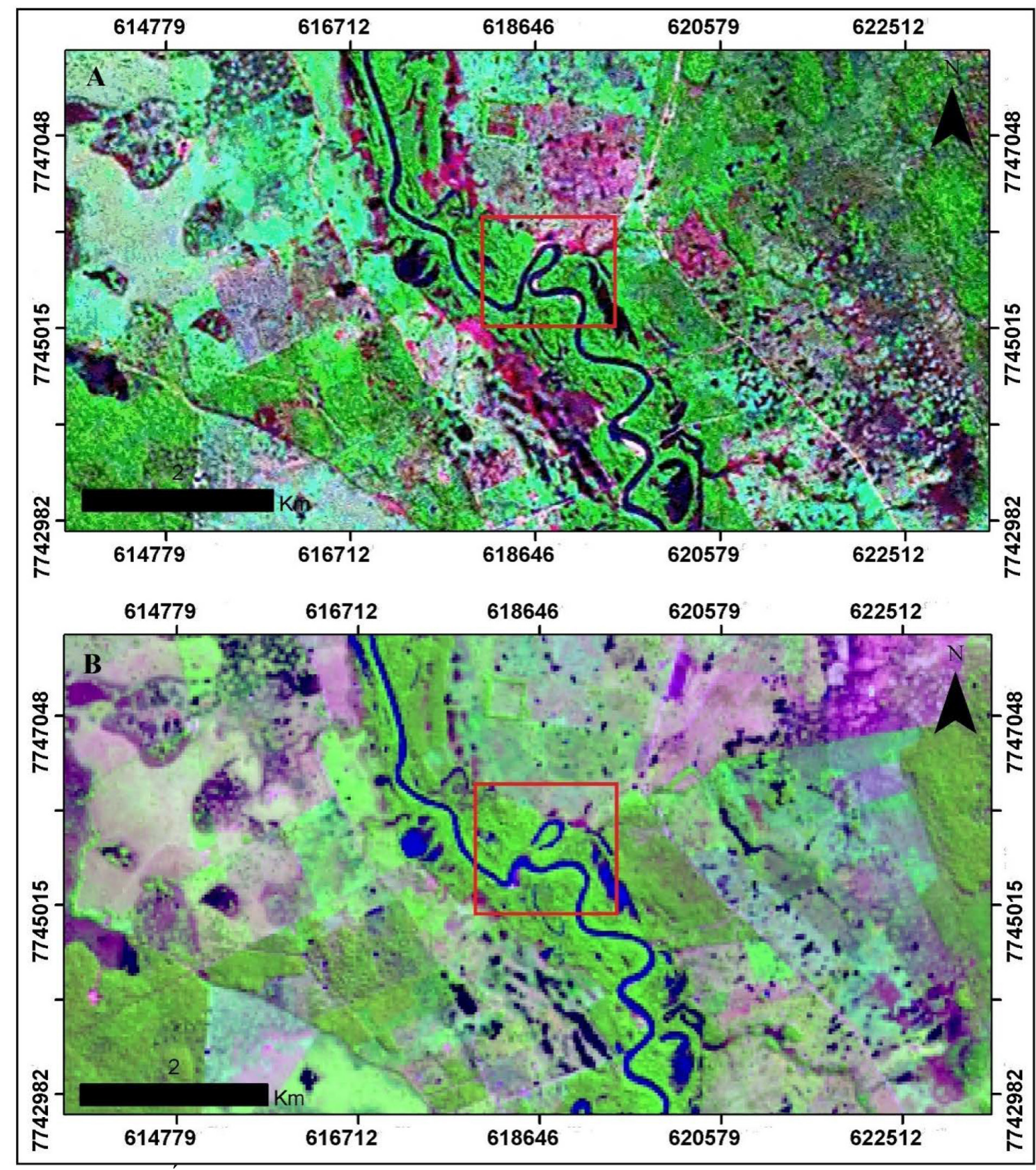

Fonte: GREGÓRIO, E. C. (2015). (A) Imagem Landsat 7/ETM+ (NASA, 2000) (B) Imagem Landsat 8/OLI (2014).

O rompimento do meandro pode resultar em duas situações, em um primeiro momento a vegetação rapidamente se regenera em seu entorno ou em alguns casos os meandros abandonados se transformam em lagoas de tamanhos diversos. Os cortes de meandros ocorrem principalmente na porção superior do cinturão de meandros atual, como exemplificado na figura 6anterior, enquanto que na porção inferior geralmente os cortes de meandros e os terraços associados diminuem ou desaparecem. 


\section{PLANÍCIE INCISA PARCIALMENTE ABANDONADA DO RIO AQUIDAUANA}

A planície incisa abandonada do rio Aquidauana possui aproximadamente $30 \mathrm{~km}$ de extensão e largura média de $2,5 \mathrm{~km}$, partindo da mudança de direção do curso do rio Aquidauana para NW até na planície do rio Negro e é essencialmente constituída por uma complexa rede de paleocanais e meandros de dimensões variadas (Figura 9).

\section{Figura 9. Planície incisa abandonada do rio Aquidauana.}

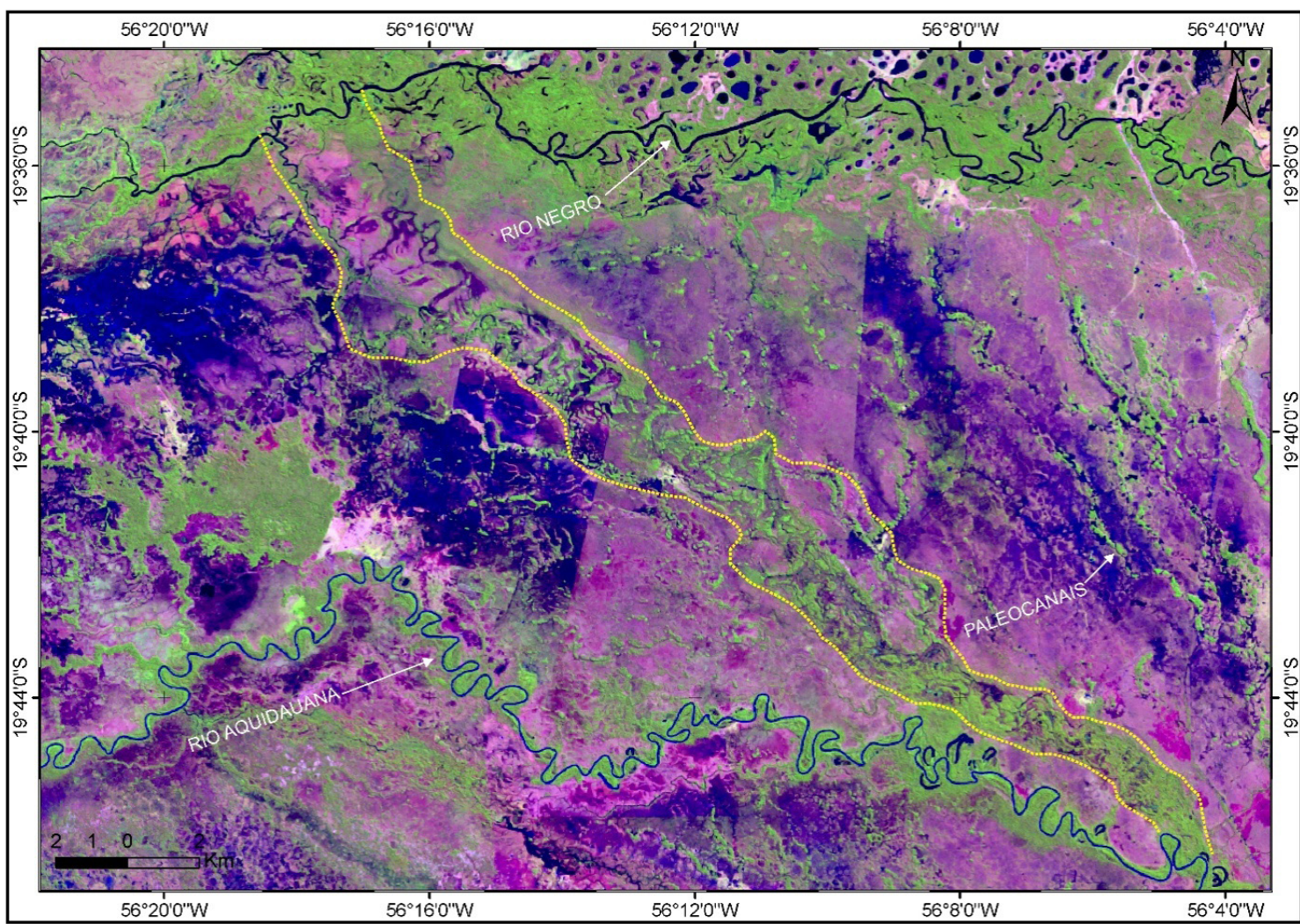

Fonte: GREGÓRIO, E. C., (2015). (Imagem LandSat 8 OLI, 20/08/2014, bandas 4B5G6R).

Na parte leste da paleoplanície tornam-se evidentes os paleocanais que indicam geoformas deposicionais mais antigas, que assim como os canais abandonados da paleoplanície são ativos durante os períodos de inundação e popularmente são conhecidos como "corixos" ou "vazantes". A existência desta unidade se dá por conta de um processo de avulsão do Rio Aquidauana, na altura da fazenda Porto das Éguas, sendo esta, a mais notável mudança paleo-hidrológica constatada no Megaleque Fluvial do Aquidauana. Este processo acarretou o abandono da antiga planície do Rio Aquidauana que em condições ambientais pretéritas tinha seu fluxo em direção norte e era afluente do Rio Negro, passando atualmente a ser afluente do Rio Miranda (Figura 10). 


\section{Figura 10. Antigo curso do rio Aquidauana.}

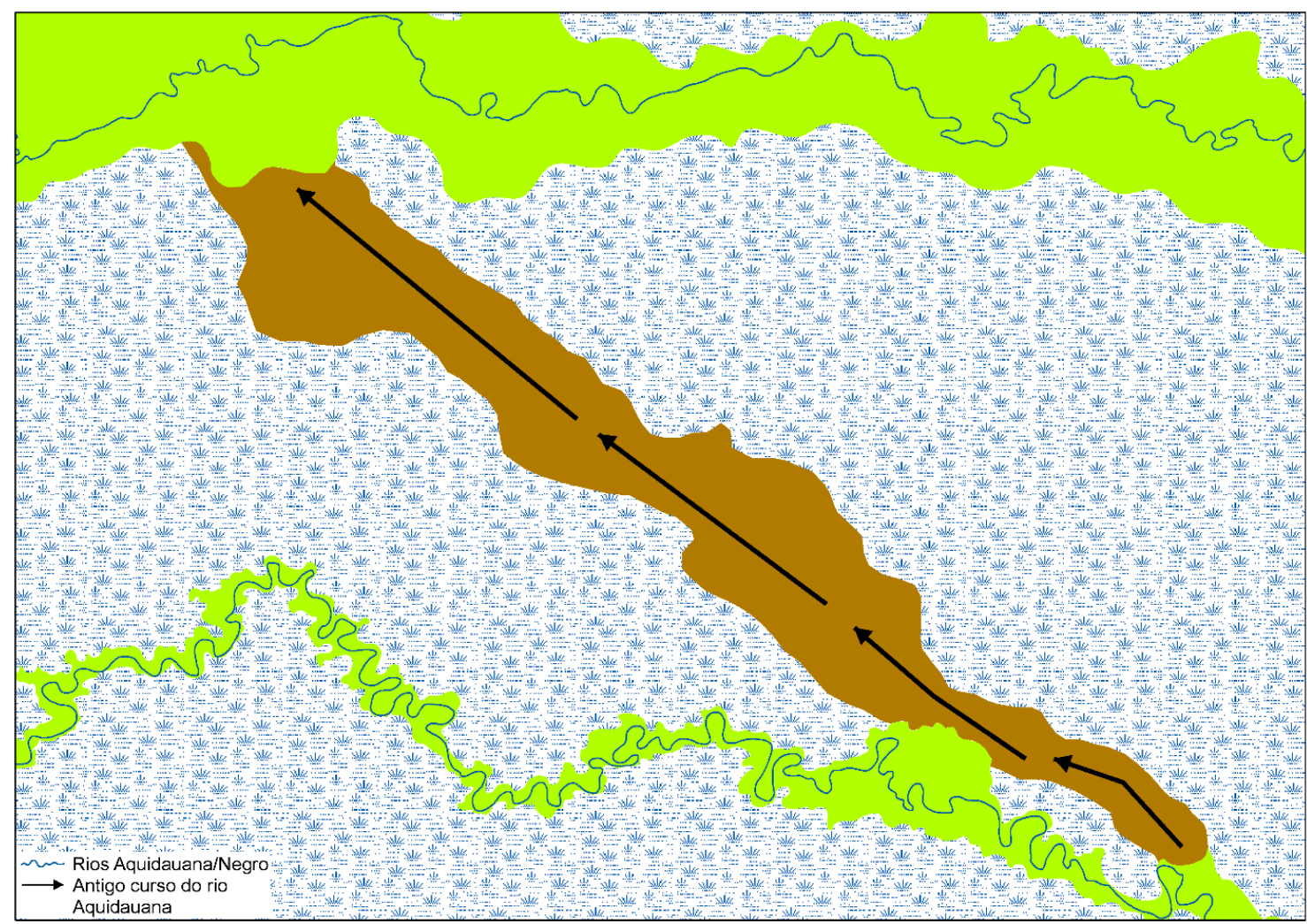

Fonte: GREGÓRIO, E.C., (2015).

As razões pelas quais o rio Aquidauana abandonou a antiga planície que chegava até o rio Negro ainda são desconhecidas, porém, sugere-se que pode ter sido por controle tectônico, uma vez que o Rio Aquidauana passou a meandrar na mesma direção de uma falha tectônica encoberta pelo rio Negro (Figura 11). 
Figura 11. Descontinuidades da área de estudo.

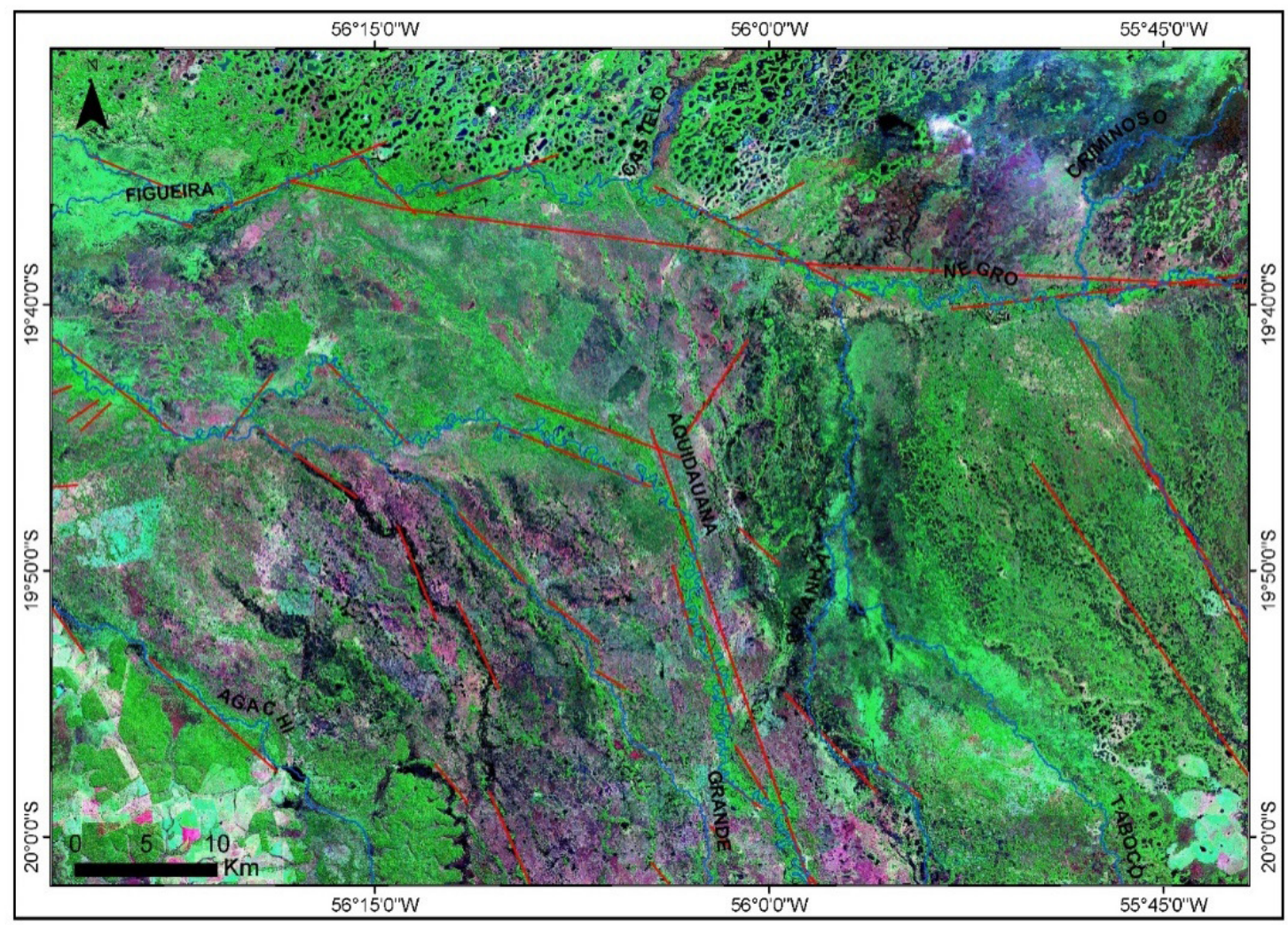

Fonte: Modificado do CPRM (2004). Imagem ZULU/NASA (2000). Elab. e Ed. GREGÓRIO, E.C. (2015).

Reativações de falhas tectônicas no Quaternário podem ter impulsionado o rio Aquidauana à brusca mudança de direção, tendo em vista que o controle por falhas tectônicas condiciona fortemente a área e isto pode estar associado às dinâmicas fluviais, como por exemplo, o cinturão de meandros abandonados do Megaleque Fluvial do Aquidauana, que está assentado sob uma falha encoberta. Quando há a deflação do rio Aquidauana em direção ao rio Miranda em alguns trechos a direção do fluxo do canal está provavelmente associada a falhas de superfícies, o que demonstra a forte relação da neoctectônica com as mudanças hidrológicas recentes. Outro fator importante que pode ser destacado na área de estudo e adjacências, assim como em outras áreas da planície pantaneira são os eventos sismológicos que estão sendo detectados com certa frequência (Figura 12). 
Figura 12. Principais sismos detectados na planície pantaneira.

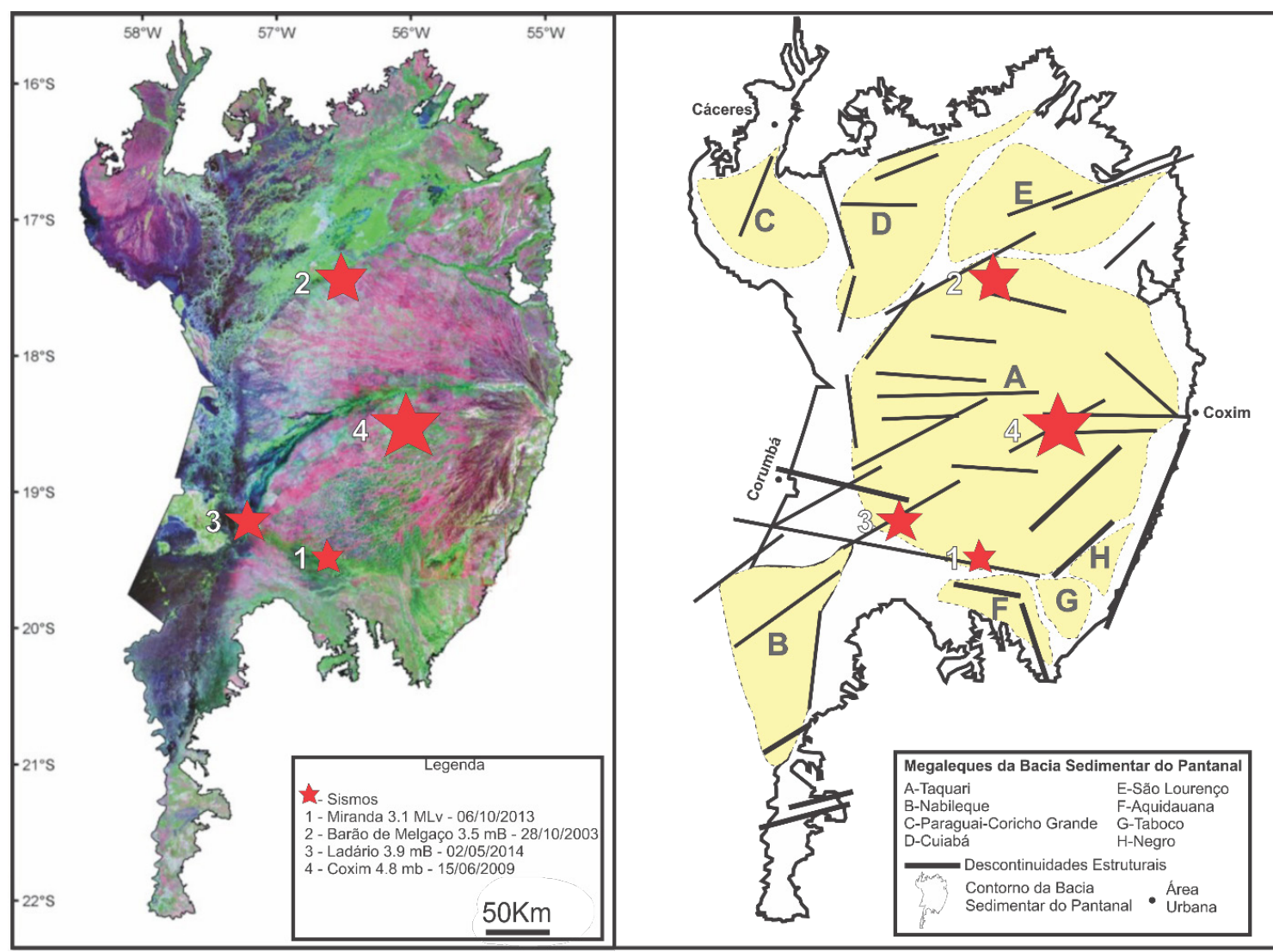

Fonte: GOMES, T. (2015). Imagem ZULU/NASA (2000).

Estes eventos ocorrem nas descontinuidades que cortam toda a planície do Pantanal e devem ser considerados importantes remodeladores da paisagem da planície, pincipalmente na dinâmica geomorfológica da área. A dinâmica fluvial e consequentemente as características morfológicas permitem associar que os padrões de forma da área do Megaleque Fluvial do Aquidauana, foram e estão sendo controladas pelas descontinuidades e tensor tectônico recente e que estão atuando de forma significativa na dinâmica geomorfológica da área.

\section{LOBOS DEPOSICIONAIS ABANDONADOS}

Os lobos deposicionais abandonados correspondem às unidades mais antigas da superfície do Megaleque fluvial do Aquidauana e estão localizados no ápice e na fração intermediária do megaleque (Figura 13), que é composto por sedimentos pleistocênicos comportando em um nível topográfico mais elevado que a planície meandrante de baixo entrincheiramento do Rio Aquidauana. 
Figura 13. Lobos deposicionais atual e relicto na superfície do Megaleque Fluvial do Aquidauana.

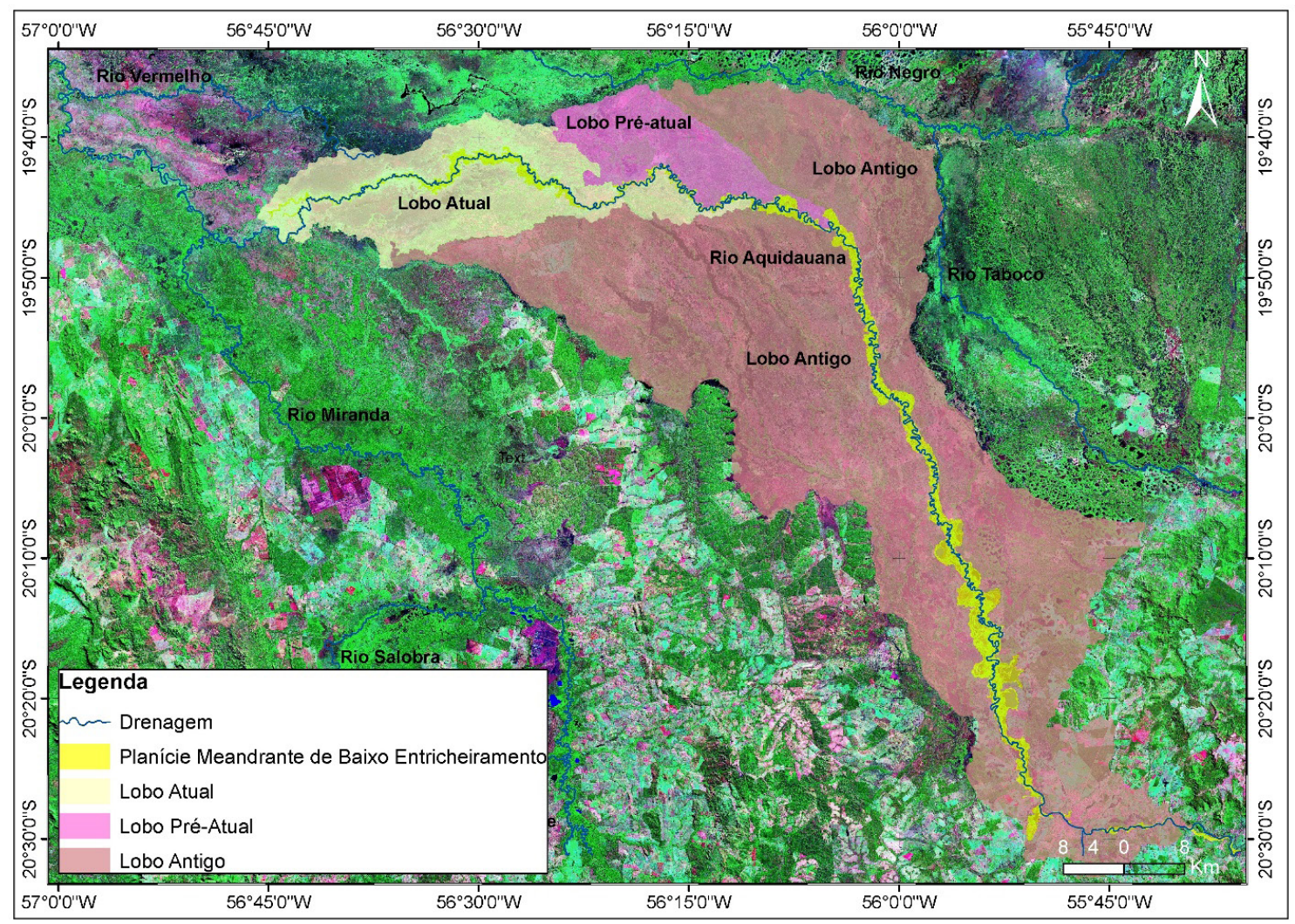

Fonte: GREGÓRIO, E. C., (2015). (Imagem Zulu, NASA, 2000).

O lobo antigo possui ápice na saída do Planalto de Maracaju/ Campo Grande e apresenta $2.758,1 \mathrm{~km}^{2}$ de área e o lobo pré-atual se inicia na altura da fazenda Porto das Éguas com superfície de $241.72 \mathrm{~km}^{2}$, sendo o menor dos lobos deposicionais identificados no Megaleque Fluvial do Aquidauana. Ambos os lobos deposicionais antigos tem limite a Norte com a planície interleque do Negro, por onde são drenadas as águas dos paleocanais ativos dos lobos abandonados durante os períodos de cheias. Estas unidades correspondem a maior parte da superfície do megaleque, que contém inúmeros paleocanais distributários deteriorados se correlacionados aos do lobo recente, no entanto, podem ser observados que estes antigos canais possuem baixa sinuosidade se comparado ao atual rio Aquidauana e constituem formas relictas que testemunham drenagem de padrão distributário.

A planície meandrante de baixo entrincheiramento do rio Aquidauana corta os lobos deposicioanais antigos por toda sua extensão. A presença do vale inciso tracejando no centro da área dos lobos antigos demostra que o mesmo está passando por processos de dissecação, predominantemente por processos fluviais erosivos. Nesta área a sedimentação ocorre principalmente em épocas de grandes inundações, formando depósitos de barras em pontal. No entanto, o processo de degradação é maior que o de agradação, uma vez que os processos erosivos são predominantes nesta área. 


\section{LOBO DISTRIBUTÁRIO ATUAL}

O lobo distributário atual do Megaleque Fluvial do Aquidauana é uma área de deposição ativa, com altitude média em torno de 95 metros, se iniciando na altura da Fazenda Porto Ciríaco, possuindo 503,88 $\mathrm{km}^{2}$ de área e aproximadamente $79 \mathrm{~km}$ de extensão do canal, até na confluência com a planície do rio Miranda, onde são encontrados uma complexa rede de paleocanais, paleodiques marginais, crevasse splays, e vários pontos de avulsionamento do rio Aquidauana (Figura 14).

Figura 14. Superfície do lobo distributário atual do Megaleque Fluvial do Aquidauana (predominam diques marginais e crevasse splays).

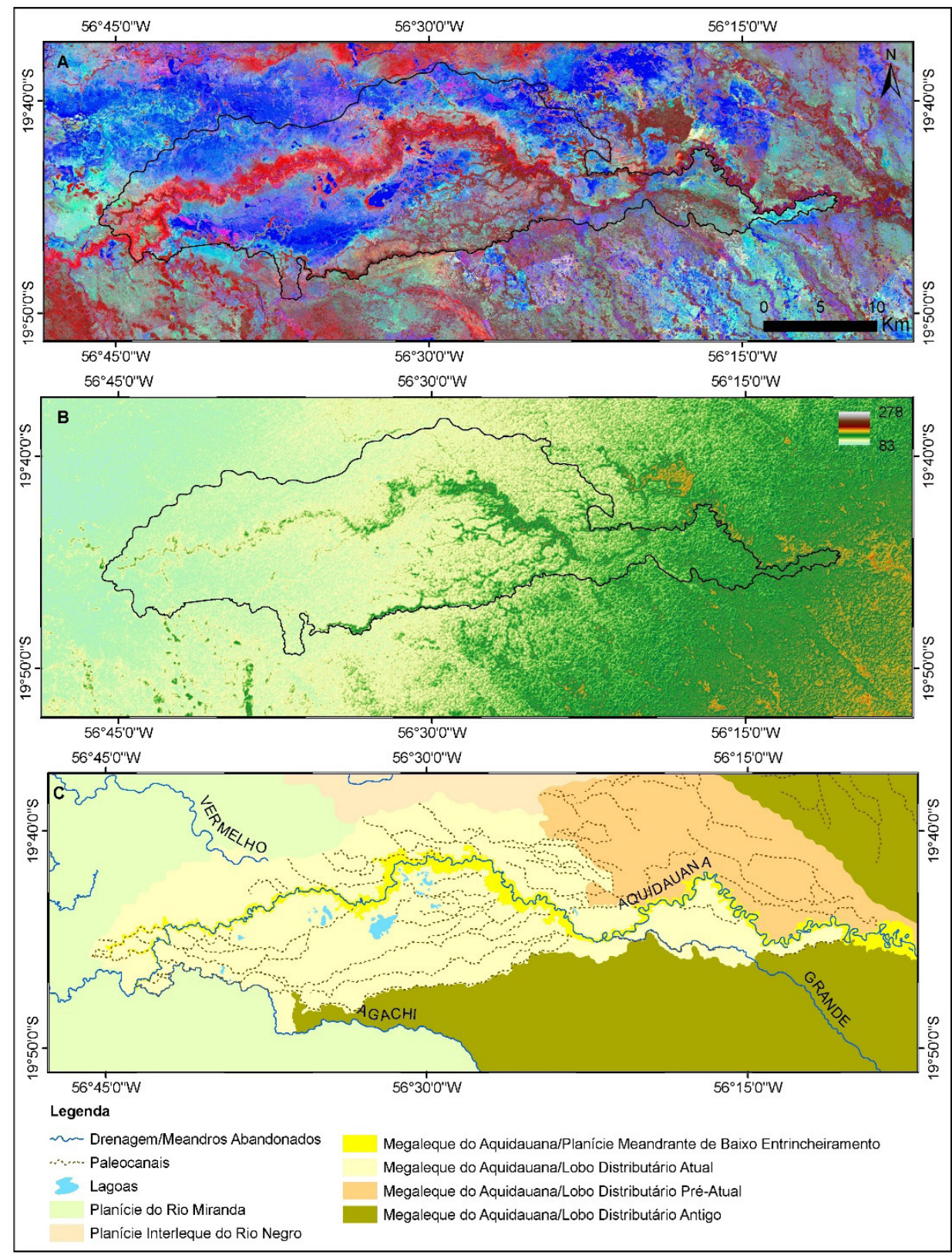

Fonte: GREGÓRIO, E.C. (2015). (A) Imagem BaseMap Arcgis ${ }^{\circledR}$ online. (B) Imagem SRTM, Topodata 30m, 
O ápice do lobo distributário atual se encontra na altura da Fazenda Porto Ciríaco, se iniciando onde termina o cinturão de meandros abandonado e os terraços marginais desaparecem. Neste compartimento há presença constante de pontos de rompimentos de diques marginais, que formam canais distributários em ambas as margens dos rios.

Nas proximidades da Fazenda Costa Rica, o canal perde água para a planície de inundação devido ao extravasamento das águas do rio nos períodos de cheias, da existência de locais de rompimentos de diques marginais e de construção de leques de espraiamento, pois, quando as águas extravasam do canal principal, fluem para a planície sobre os diques marginais arrombando-os, formando os leques de crevasse (Figura 15).

\section{Figura 15. Paleodiques marginais no lobo distributário atual do Megaleque do Aquidauana.}
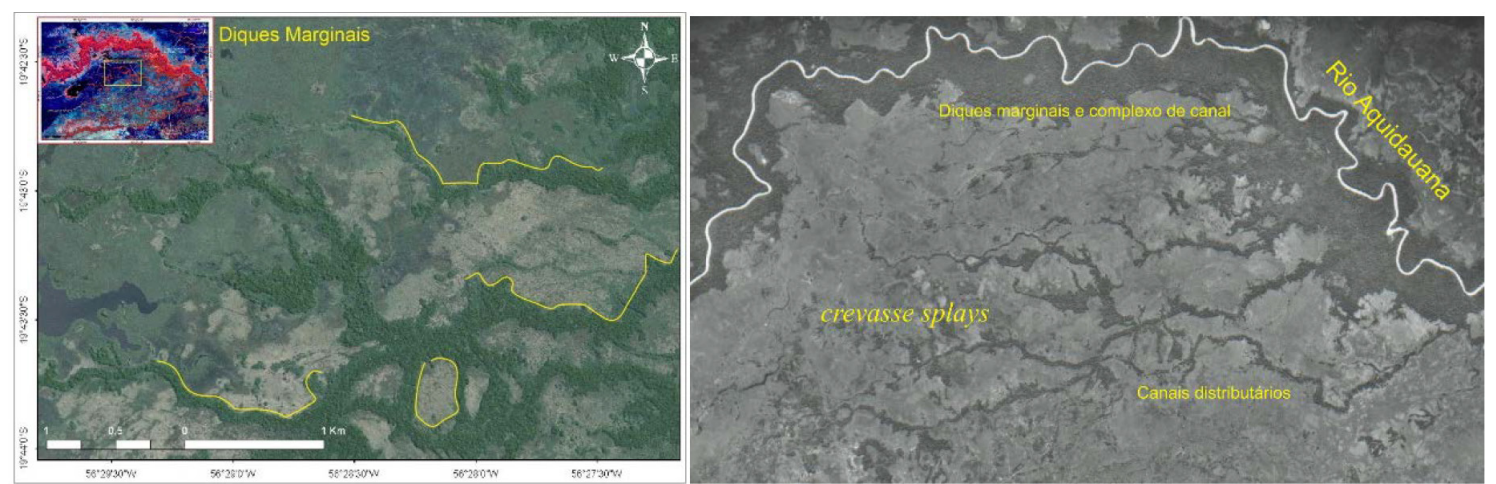

Fonte: AMORIM, G. M.; (2015). Imagem Bing Arcgis ${ }^{\circledR}$ online.

Nesta área, a planície permanece periodicamente alagada devido à perda de água do canal para a planície e associado a isto, as águas dos rios Miranda e Negro fluem para esta direção nos períodos de inundação, o que por ser a área com menor cota altimétrica da superfície do Megaleque Fluvial do Aquidauana, se comporta como o nível de base local apresentando altitudes $\mathrm{m}$ torno de $90 \mathrm{~m}$ acima do nível do mar e marcada por sedimentação atual.

\section{PROCESSOS DE AVULSÃO}

Os processos de avulsão são frequentes nos lobos distributários pré-atual e atual do Megaleque Fluvial do Aquidauana, na forma de rompimentos dos canais com eventual formação de leques de crevasse, o que comprova as várias mudanças no curso do rio durante o Quaternário.

O processo de avulsão mais notável se encontra-se no lobo pré-atual do megaleque quando o rio muda abruptamente de direção e que foi classificado neste trabalho como a planície incisa abandonada do Rio Aquidauana em torno de $37 \mathrm{~km}$ de extensão. No entan- 
to, na sua porção inferior, onde está o lobo distributário atual, estes fenômenos têm ocorrido com bastante frequência. O ponto de avulsionamento mais perceptível nesse compartimento, recebe o nome de Aquidauaninha (Figura 16) e permanece ativo durante o período de cheias, assim como vários outros canais abandonados observados nesta área.

\section{Figura 16. Avulsionamento no lobo distributário atual do Megaleque do Aquidauana (destaque} ao paleocanal: Aquidanauinha).

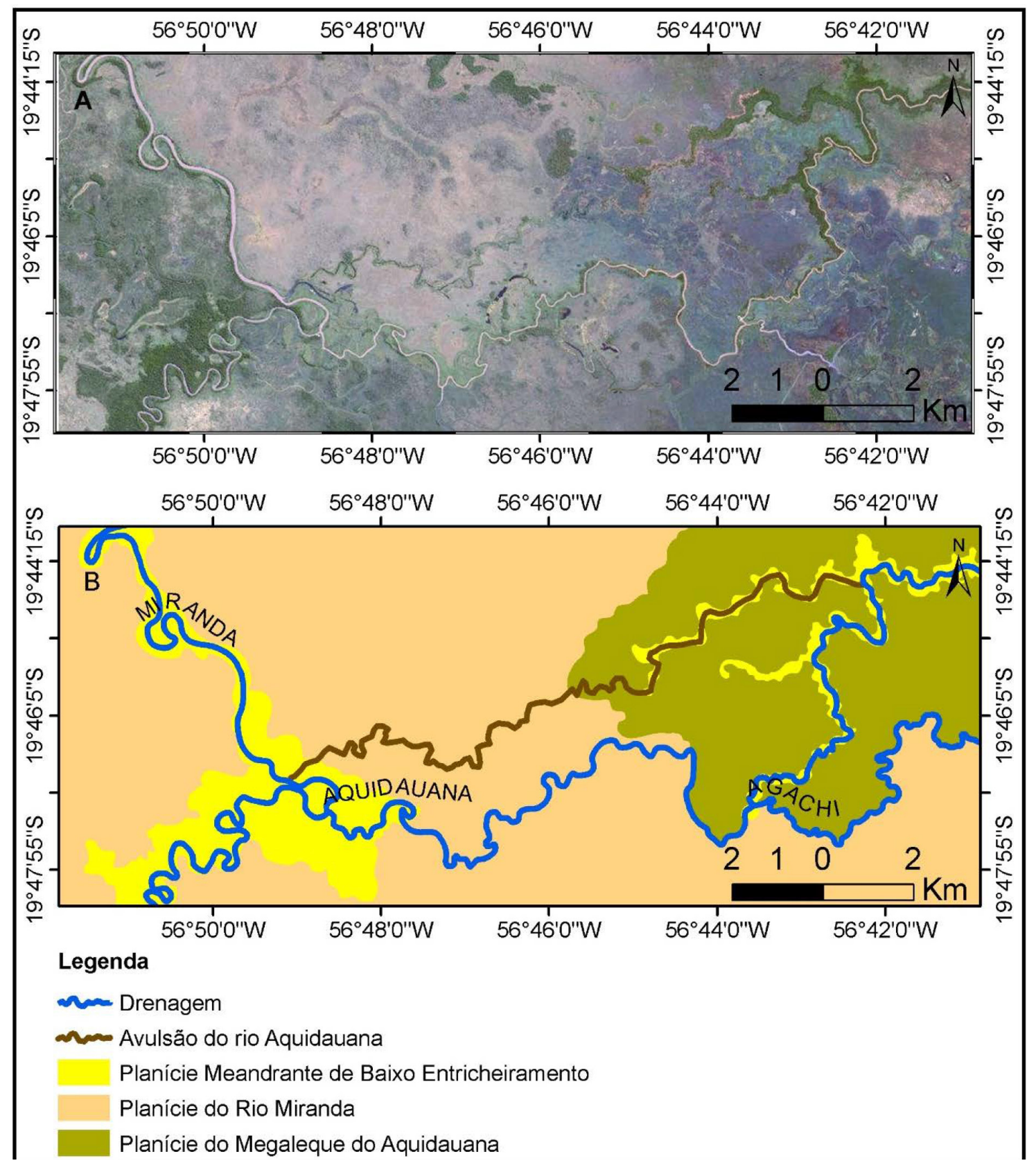

Fonte: GREGÓRIO, E. C. (2015). (A) Imagem BaseMap Arcgis ${ }^{\circledR}$ online. (B) Mapeamento elaborado. 
Os processos de avulsão são frequentes nesta área devido à alta carga de sedimentos erodidos da bacia de captação das áreas de planaltos adjacentes ao Megaleque Fluvial do Aquidauana e dos terraços dos lobos antigos e que estão sendo depositados na área. Uma parte destes sedimentos se acumula no canal do rio e provoca assoreamento por agradação, o que, associado com a acumulação progressiva ao longo do tempo faz com que o canal se comporte em uma altura superior a planície de inundação do rio, ocasionando extravasamento das águas do canal. Nas áreas onde ocorre o rompimento do canal a águas e os sedimentos são transportados para esta área onde se instala um novo canal.

A superfície do Megaleque Fluvial do Aquidauana na sua porção distal é caracterizada pela presença de inúmeros paleocanais distributários. Sedimentação atual ocorre principalmente no lobo distributário atual (holocênico) na parte distal, situado numa ampla planície onde coalescem canais anastomosados dos rios Aquidauana e Miranda.

\section{DISCUSSÃO DOS RESULTADOS}

A compreensão das geoformas presentes e atuantes na superfície do Megaleque Fluvial do Aquidauana ocorre pelo entendimento de que o Pantanal é uma bacia sedimentar quaternária ativa, preenchida por um trato deposicional predominantemente aluvial composto por vários megaleques fluviais.

As feições geomorfológicas do Pantanal são formas relíquiares (Tricart, 1982; Ab’saber, 1988; Assine, 2003; Assine e Soares, 2004) que resultaram de uma sucessão de eventos correlacionados com mudanças ambientais e decorrentes de oscilações no nível de base, na da precipitação e da descarga fluvial que vem incidindo na planície pantaneira desde o final do Pleistoceno (De Azevedo Macedo et al., 2014).

O Rio Aquidauana apresenta características similares ao de outros rios do Pantanal, destacando-se o fato de construir um megaleque fluvial, com morfologia distinta nos diferentes compartimentos em que o Rio Aquidauana percorre.

O Megaleque Fluvial do Aquidauana, assim como outros megaleques fluviais que compõe o trato deposicional do Pantanal é uma grande feição geomorfológica formada provavelmente no final do Pleistoceno durante um clima semi-árido e o atual Pantanal como o conhecemos surgiu na transição Pleistoceno/Holoceno em um sistema climático mais úmido no início do Holoceno (Ab’saber, 1988; Clapperton, 1993; Latrubesse et al., 2005; Assine, 2012). Especificamente as características atualmente visíveis só podem ter se constituído no último intervalo de aridez, o que corresponderia à última glaciação, na qual a sedimentação continuou atuando durante o Holoceno (Assine e Soares, 2004). 
Na porção proximal do Megaleque do Aquidauana, o cinturão de meandros atual de idade Holocênica está confinado em uma planície incisa limitada por terraços provavelmente de idade Pleistocênica, construído pela sedimentação de lobos deposicionais abandonados. A idade atribuída seria holocênica (1 a $3 \mathrm{ka}$ AP) para o cinturão de meandros atual e Pleistocênica (10 e $70 \mathrm{Ka} \mathrm{AP}$ ) para os terraços que foram identificados por Assine e Silva (Assine e Silva, 2009) e Silva (Silva, 2010).

Nas adjacências do cinturão de meandros atual do Megaleque Fluvial do Aquidauana são encontrados paleocanais que evidenciam padrão de drenagem distributários na parte superior do megaleque, o que demonstra que o padrão distributário se estabeleceu primeiro nesta área e que ao longo do tempo foi sedimentando, formando os terraços marginais que atualmente são responsáveis pelo entalhamento do Rio Aquidauana em uma planície incisa holocênica. Este compartimento na fração proximal do Megaleque do Aquidauana corresponde a um lobo deposicional antigo que foi abandonado após sofrer acomodação dos sedimentos oriundos dos planaltos adjacentes.

Analogamente, o confinamento do Rio Aquidauana em uma planície incisa, encravada em depósitos pleistocênicos pode ter ocorrido de forma semelhante ao do Megaleque do São Lourenço (Corradini e Assine, 2012). Devido a significativas alterações climáticas que sucederam no Pantanal do final do Pleistoceno ao Holoceno Médio (Assine e Soares, 2004) houveram oscilações no perfil de equilíbrio do rio São Lourenço, o que ocasionando a incisão do canal. Considerando a mesma hipótese para o Rio Aquidauana, a incisão instalada em depósitos mais antigos pode ter ocorrido no final do Pleistoceno e início do Holoceno. Neste sentido, as incisões oriundas da queda de nível de base são classificadas como frequentes em megaleques fluviais, sejam por mudanças climáticas e/ou por eventos tectônicos (Corradini e Assine, 2012).

Na deflação do Rio Aquidauana para WNW, ocasionado por um processo de avulsão para o rio Negro, se encontra uma planície incisa abandonada, constituída por paleobarras em pontal, paleodiques marginais e altos índices de paleomeandros abandonados. Isto fica evidenciado em imagens ópticas, nas quais são observados paleomeandros significativos e relíquias da paleodrenagem do antigo curso do rio Aquidauana.

Neste trabalho se considerada a hipótese de que houve um processo de avulsão fluvial do atual Rio Aquidauana, afluente do Rio Miranda, ocasionado por uma sucessão de eventos alocíclico (tectônica), evidenciado pelo controle estrutural de falhas, além de sismos pretéritos ocorridos na área. Este tipo de evento foi constatado por Kuerten (Kuerten et al., 2009; Kuerten, 2010) no Megaleque do Rio Nabileque e em ambos estudos o Rio 
Nabileque foi considerado como um processo de avulsão do rio Paraguai, com a junção de fenômenos autocíclicos e alocíclicos. No caso do fenômeno alocícliclo ocorrido no Rio Nabileque, o processo foi fortemente influenciado por controle tectônico, uma vez que o rio passou a ter direção NE, coincidindo com a direção do Lineamento Transbrasiliano.

O fato mais interessante é que não se pode fundamentar com exatidão em que período ocorreu o processo de avulsão do rio Aquidauana, uma vez que seria preciso usar métodos de datação de sedimentos específicos, mas o que se fica evidente em imagens de satélites é que a jusante (proximidades do rio Negro) o trecho de abandono apresenta alto índice de sinuosidade, característica de alta atividade hídrica neste setor. Outro fato que corrobora com esta hipótese é a variação altimétrica neste ambiente, que apresenta $122 \mathrm{~m}$ no ponto superior da avulsão e $107 \mathrm{~m}$ nas proximidades do rio Negro. Nesta situação este compartimento seria considerado um lobo deposicional pré-atual e a alta atividade hídrica na porção inferior do paleocanal do Rio Aquidauana seria ocasionada por frequentes inundações e por conta do extravasamento das águas do canal enquanto este lobo permanecia ativo, fato que ocorre no lobo distributário atual do Megaleque Fluvial do Aquidauana.

O lobo distributário pré-atual do Megaleque Fluvial do Aquidauana é um ambiente ativo em épocas de grandes cheias, constituídos por terras baixas frequentemente inundadas. O processo de avulsão do rio Aquidauana, assim como constatado em outros Megaleques como os do Taquari (Assine, 2003; Zani, 2008), do Nabileque (Kuerten, 2010) e no Paraguai (Silva, 2010), são fenômenos de ordem natural em busca de um equilíbrio do próprio sistema, sendo comum em ambientes de deposição atual.

O lobo distributário atual do Megaleque Fluvial do Aquidauana apresenta morfologia distinta do lobo antigo e pré-atual. Neste compartimento localizado na porção distal do sistema, existe uma rede complexa de paleocanais, diques marginais, crevasse splays e frequentes processos de avulsão.

As geoformas encontradas no lobo distributário atual do Megaleque Fluvial do Aquidauana são encontradas em outros lobos deposicionais ativos na planície pantaneira, como descrita no lobo ativo do Megaleque do Taquari (Assine, 2003; Zani, 2008), no Taboco (Facincani, 2007), no Negro (Cordeiro et al., 2010), no Paraguai (Silva, 2010) e no São Lourenço (Corradini e Assine, 2012).

O lobo deposicional ativo está instalado na fração distal do Megaleque Fluvial do Aquidauana, onde existe um amplo espaço para acomodação de sedimentos e uma área com altitudes inferiores as encontradas na porção superior. Na porção proximal a altitude encontra é de 145 metros enquanto que a fração distal está a 95 metros e isto facilita o 
escoamento das águas do rio Aquidauana em períodos de cheias, o que consequentemente seria responsável pelas morfologias encontradas na área e na constituição do lobo deposicional ativo.

Os lobos deposicionais ativos dos Megaleques que compõe o trato deposicional da Bacia do Pantanal geralmente são encontrados na parte distal do sistema, assim como evidenciado no Megaleque do Aquidauana. Esta característica dos lobos deposicionais ativos são encontrados em diversos trabalhos (Assine, 2003; 2005; Zani, 2008; Zani et al., 2009) Megaleque do Taquari (Assine, 2003; Zani, 2008), no Taboco (Facincani, 2007), no Negro (Cordeiro et al., 2010), no Paraguai (Silva, 2010) e no São Lourenço(Corradini e Assine, 2012).

Os complexos de canais e diques marginais recentes formam superfícies lobadas, constituídas principalmente por areia (Assine, 2005; Zani et al., 2009), na porção distal do Megaleque do Taquari e que esta característica está de acordo com as interpretações feitas por Slingerland e Smith (Slingerland e Smith, 2004), onde rios aluviais como os encontrados no Pantanal são passíveis de sedimentação nas áreas distais. Este tipo de processo também está ocorrendo atualmente na porção distal do Megaleque Fluvial do Aquidauana, onde está instalado o lobo distributário atual.

A alteração do nível de base no Megaleque do Aquidauana pode ser responsável pela mudança de lugar dos lobos, que causam a incisão dos rios por processos erosivos, ressalta-se que caso isto não ocorresse os sedimentos depositados subsequentes elevariam o nível de base e tomariam o canal distributário novamente, fazendo com a sedimentação no ambiente superior do leque e no canal a montante ultrapassasse a carga máxima nominal. Processos ocasionados por fenômenos autocíclicos estão geralmente associados à evolução de leques aluviais, conforme constatado por Silva (Silva, 2010).

\section{CONSIDERAÇÕES FINAIS}

O Megaleque Fluvial do Aquidauana tem sido palco de frequentes mudanças ambientais desde o final do Pleistoceno até o presente, principalmente as de cunho hidrológico e apresenta diversas feições atuais e reliquiares, o que evidencia a evolução gemorfológica durante o Quaternário.

Paleocanais distributários e processos de avulsão fluvial são as principais evidências de mudanças ambientais, corroborando com a hipótese de que as mudanças estão intrinsecamente correlacionadas com os eventos geomorfológicos, que constantemente remodelam a paisagem do Megaleque Fluvial do Aquidauana. 
A proposta de criar compartimentos geomorfológicos permitiu avaliar que a superfície do Megaleque Fluvial do Aquidauana é marcada por uma sucessão de abandono e construção de lobos deposicionais, processos de incisão fluvial na fração superior e criação de áreas de agradação de sedimentos oriundos dos planaltos adjacentes e de áreas de degradação do próprio megaleque, na sua porção mais inferior.

$\mathrm{Na}$ área de estudo, os fenômenos alocíclicos e autocíclicos alteram áreas onde ocorrem erosão, transporte e sedimentação, transformando a superfície do megaleque em áreas distintas, com padrões de forma peculiar a cada unidade geomórfica compartimentada. De fato, meandros abandonados, barras em pontal, terraços marginais e lagoas em meandros são comuns no lobo antigo, instalado no ápice do megaleque, enquanto que no lobo atual são frequentes paleocanais distributários e paleodiques marginais, no entanto, este conjunto de fenômenos e formas observados, são as que tornam a paisagem da área mutante.

A complexa rede de paleocanais e os processos de avulsão documentados confirmam que as mudanças do curso do Rio Aquidauana fazem parte da dinâmica do sistema deposicional à que este está submetido e entender a magnitude e o marco temporal em que estão situados e ocorrem é fundamental para que se entenda de forma satisfatória o ciclo geomorfológico da área. Concomitante ao entendimento da evolução geomorfológica é possível presumir futuras mudanças ambientais da área e prognosticar alterações do curso do Rio Aquidauana. Disto ressalta-se que a compreensão dos processos sedimentares que ocorrem em megaleques fluviais, como o do Aquidauana é de grande relevância para entender a gênese e a evolução da planície pantaneira como um todo e traçar metas de preservação adequadas para este ambiente que está em constante evolução.

Em termos metodológicos, enfatiza-se o uso das geotecnologias e do sensoriamento remoto para a compartimentação geomorfológica, identificação e interpretação dos principais elementos geomórficos que compõe a superfície do Megaleque Fluvial do Aquidauana. Espera-se que com os resultados obtidos, se entenda melhor o complexo geomorfológico da planície pantaneira, sobretudo em sua borda sudeste em que estudos desta natureza ainda são incipientes. 


\section{AGRADECIMENTOS}

Os autores agradecem a Fundação de Apoio ao Desenvolvimento do Ensino, Ciência e Tecnologia do Estado de Mato Grosso do Sul (Edital de chamada FUNDECT/CAPES no 02/2014 - Protocolo 28.758.415.2497.31032014), pela concessão de bolsa de estudo de mestrado para Eliezer Cece Gregório, o que possibilitou a realização deste trabalho.

Os autores agradecem novamente a Fundação de Apoio ao Desenvolvimento do Ensino, Ciência e Tecnologia do Estado de Mato Grosso do Sul - FUNDECT, pela concessão da Bolsa de Desenvolvimento Científico Regional, concedida a Gustavo Marques e Amo$\operatorname{rim}($ T.O.140/2014).

\section{REFERÊNCIAS}

1. AB'SABER, A. N. O Pantanal Mato-Grossense e a teoria dos refúgios. Revista Brasileira de Geografia. Rio de Janeiro, RJ: SECRETARIA DE PLANEJAMENTO E COORDENAÇÃO DA PRESIDÊNCIA DA REPÚBLICA - FUNDAÇÃO INSTITUTO BRASILEIRO DE GEOGRAFIA E ESTATÍSTICA-IBGE 50: 146 p. 1988.

2. ASSINE, M. L. Sedimentação na bacia do Pantanal mato-grossense, centro-oeste do Brasil. 2003.

3. River avulsions on the Taquari megafan, Pantanal wetland, Brazil. Geomorphology, v. 70, n. 3, p. 357-371, 2005. ISSN 0169-555X.

4. ___ Pantanal Mato-Grossense: Uma Dádiva Geológica. In: BECA (Ed.). Geologia do Brasil. São paulo: Beca, v.1, 2012. cap. 24c, p.623-628.

5. ASSINE, M. L.; SILVA, A. Contrasting fluvial styles of the Paraguay River in the northwestern border of the Pantanal wetland, Brazil. Geomorphology, v. 113, n. 3, p. 189-199, 2009. ISSN 0169-555X.

6. ASSINE, M. L.; SOARES, P. C. Quaternary of the Pantanal, west-central Brazil. Quaternary International, v. 114, n. 1, p. 23-34, 2004. ISSN 1040-6182.

7. CLAPPERTON, C. Quaternary geology and geomorphology of South America. 1993. ISBN 0444882472.

8. CORDEIRO, B. M. et al. Compartimentação geomorfológica do leque fluvial do rio Negro, borda sudeste da Bacia do Pantanal (MS). Revista Brasileira de Geociências, v. 40, n. 2, p. 175-183, 2010. ISSN 0375-7536. Disponível em: < http://www.rbg.sbgeo.org.br/index.php/ rbg/article/viewFile/14682/1204 >.

9. CORPORATION, G.-I. Google Earth. California: Google - International Corporation. 6: Snapshot - Cuiabá, Mato Grosso do Sul, Brasil. Latitude: -15.5989, Longitude: -56.0949 $15^{\circ}$ 35 '56” p. 2015. 
10. CORRADINI, F. A.; ASSINE, M. L. Compartimentação geomorfológica e processos deposicionais no megaleque fluvial do rio São Lourenço, Pantanal mato-grossense. Revista Brasileira de Geociências, v. 42, p. 20-33, 2012. ISSN 0375-7536.

11. DE AZEVEDO MACEDO, H. et al. MUDANÇAS PALEO-HIDROLÓGICAS NA PLANÍCIE DO RIO PARAGUAI, QUATERNÁRIO DO PANTANAL LATE QUATERNARY PALEOHYDROLOGICAL CHANGES IN THE PARAGUAY FLUVIAL PLAIN, BRAZILIAN PANTANAL WETLAND. Revista Brasileira de Geomorfologia, v. 15, n. 1, 2014.

12. FACINCANI, E. M. Geomorfologia e Geologia do Cenozóico do Médio Vale do Rio Aquidauana, Borda Sudeste da Bacia do Pantanal, MS. Relatório de Pós-Doutorado. Curso de Pós-Graduação em Geociências e Meio Ambiente-Rio Claro, p. 100, 2007.

13. KNIGHT, E. J.; KVARAN, G. Landsat-8 operational land imager design, characterization and performance. Remote Sensing, v. 6, n. 11, p. 10286-10305, 2014.

14. KUERTEN, S. Evolução geomorfológica e mudanças ambientais no megaleque do Nabileque, Quaternário do Pantanal Mato-Grossense. 2010.

15. KUERTEN, S. et al. Rio Nabileque: antigo curso do rio Paraguai. Anais, v. 2, p. 194-201, 2009.

16. LATRUBESSE, E. M. et al. Grandes sistemas fluviais: geologia, geomorfologia e paleoidrologia. In: SOUZA, C. R. G.;SUGUIO, K., et al (Ed.). Quaternário do Brasil. São Paulo: Holos, v.1, 2005. cap. 12, p.276-297.

17. SILVA, A. Geomorfologia do megaleque do rio Paraguai, Quaternário do Pantanal Matogrossense, centro-oeste do Brasil. 2010.

18. SLINGERLAND, R.; SMITH, N. D. River avulsions and their deposits. Annu. Rev. Earth Planet. Sci., v. 32, p. 257-285, 2004. ISSN 0084-6597.

19. SOARES, P. C.; FIORI, A. P. Lógica e sistemática na análise e interpretação de fotografias aéreas em geologia. Campinas-São Paulo, p. 71-140, 1976.

20. TRICART, J. El Pantanal: un ejemplo del impacto geomorfologico sobre el ambiente. Investigaciones Geográficas, n. 29, p. Pág-81, 1982. ISSN 0719-5370.

21. VALERIANO, M. D. M. TOPODATA: guia de utilização de dados geomorfométricos locais. São José dos Campos: INPE, 2008.

22. ZANI, H. Mudanças morfológicas na evolução do megaleque do Taquari: uma análise com base em dados orbitais. 2008. Dissertação de Mestrado. Instituto de Geociências e Ciências Exatas.Unesp-Rio Claro-SP.

23. ZANI, H. et al. Redes de drenagem distributária e formas deposicionais no megaleque do Taquari, Pantanal: uma análise baseada no MDE-SRTM. Revista Brasileira de Geomorfologia, v. 10, n. 2, 2009. ISSN 2236-5664.

Artigo recebido em 31 de maio de 2016. Artigo aceito em 04 de novembro de 2016. 